\title{
The Roosevelt All-Party Agricultural Committee and the 1936 Election
}

\author{
Thomas T. SPENCER
}

DURING THE 1936 presidential campaign, Franklin Roosevelt and the Democratic party made a major effort to attract voters they felt had a vital stake in the New Deal relief and recovery programs. Included among these voter groups were black Americans, women, laborers, and farmers. Farmers, particularly those in the Midwest, were especially important to the Democrats in 1936. Democratic strategists believed the midwestern farm belt was crucial to the president's reelection effort and they hoped that such New Deal achievements as the Agricultural Adjustment Act, soil conservation programs, rural electrification, the Farm Credit Administration, and drought relief, would help keep farmers in the Roosevelt fold.

Despite the benefits farmers had achieved under the New Deal, putting the farm vote in the Roosevelt column was not a sure thing. Southern farmers were relatively content with economic conditions, but in the Midwest it was a different story. Unlike southern farmers, agriculturalists in the Midwest had suffered from the disastrous effects of a severe drought in the summer of 1936. In addition, midwestern farmers were upset with the effects of the foreign trade program on their livelihood. ${ }^{1}$ Central to the government's foreign trade program

\footnotetext{
"Bernhard Ostrolenk, "In the South the Farmer is Cheerful," New York Times Magazine, August 30, 1936, 5; Christiana Campbell, The Farm Bureau
} 
were the reciprocal trade agreements with Cuba, Belgium, Sweden, Haiti, Brazil, Colombia, and Canada that were passed during Roosevelt's first administration. Many midwestern farmers opposed these agreements, especially the one with Canada. Wisconsin's dairy farmers, for example, were upset with the agreement because it admitted Canadian cheddar cheese and dairy cattle at reduced rates. Nebraska farmers were also upset over the admission of Canadian cattle at lower tariff rates. $^{2}$

Other factors caused concern at Democratic headquarters as well. Farmers in the Midwest were traditionally Republican and the nomination of Alfred Landon of Kansas as the Republican presidential candidate bolstered Republican hopes of carrying the farm vote in that area. Many Democratic leaders were worried, too, about the apparent drop in enthusiasm for the New Deal during the summer months. A Gallup Poll taken from July $20-25,1936$, showed 46.1 per cent of midwestern farmers for Roosevelt, but 45.7 per cent for Landon. An August poll showed the states of Iowa, Illinois, Indiana, South Dakota, Minnesota, and Ohio to be borderline in favor of the Republicans, with Nebraska and Kansas safely in the Landon column. A poll by The Farm Journal also indicated that many of the midwestern states were for Landon. ${ }^{3}$ Reports from various Democratic leaders, such as Frank Murphy in Minnesota and

and the New Deal: 1933-1940 (Urbana, 1962), 107; This is not to imply southern farmers were prosperous. Southern agriculture had not reached pre-deression levels and many tenant farmers were left untouched by New Deal policies. Southern farmers, however, did not feel the effects of the drought and the Canadian trade agreement as did their midwestern counterparts.

${ }^{2}$ Arthur W. Schatz, "The Reciprocal Trade Agreements Program and the Farm Vote," Agricultural History, 46 (October, 1972): 508; Francis B. Sayre, "The United States-Canadian Trade Agreement," The Democratic Digest, January, 1936, 6; Harold Gosnell and Morris Cohen, "Progressive Politics; Wisconsin an Example," The American Political Science Review, 34 (October, 1940): 924; Arthur Sears Henning, "New Deal Tariff Policy Alienates Nebraskans," Los Angeles Times, October 4, 1936.

${ }^{3}$ Edward and Frederick Schapsmeier, Henry $A$. Wallace of lowa: The Agrarian Years 1910-1940 (Ames, Iowa, 1965), 229; Washington Evening Star, June 14, 1936; George Gallup, The Gallup Poll: Public Opinion 19351971, 1 (New York, 1972): 32-33; New York Times, November 2, 1936. 


\section{The Annals of Iowa}

Paul Porter in Iowa, portrayed the situation in those states as bad or doubtful and added to the concern at Democratic headquarters. ${ }^{4}$

Along with this pessimistic outlook, there were New Deal opponents to be reckoned with. In 1935, the Farmers Independence Council of America was established. This group was closely related to the American Liberty League, a wealthy, antiNew Deal organization, and throughout 1936 it served as an active propaganda organ for material critical of the administration's farm program. Democratic leaders were also upset about the harmful effect of rumors from different sources that the Agricultural Adjustment Administration was destroying large quantities of food in its efforts to raise prices through shortage of farm goods. ${ }^{5}$

It is against this background and with these problems in mind that the Roosevelt All-Party Agricultural Committee was formed in August, 1936. The purpose of the committee was to organize farmers behind Roosevelt and help counter anti-administration propaganda concerning New Deal farm policies. The idea for such a group originated with Secretary of Agriculture Henry Wallace and Agricultural Adjustment Administrator Chester Davis. Davis and Wallace met late in June with William Settle, an Indiana farmer long active in agricultural affairs, to lay plans for a committee that would appeal to members of all parties and operate outside of the regular party organization. A similar type committee had been formed for $\mathrm{Al} \mathrm{Smith} \mathrm{in} \mathrm{the}$ 1928 campaign and some of the leaders of that group, including Davis and Settle, were to play a major role in the All-Party Agricultural Committee. ${ }^{6}$

${ }^{4}$ Frank Murphy to Jim Farley, July 18, 1936, Minnesota folder \#2, Official File 300, Democratic National Committee Records, Franklin D. Roosevelt Library, Hyde Park, New York; Paul Porter to Henry A. Wallace, September 18, 1936, Correspondence, Henry A. Wallace Papers, University of Iowa, Iowa City, Iowa.

${ }^{5} J a m e s$ C. Carey, "The Farmers Independence Council of America, 19351938," Agricultural History, 35 (April, 1961): 73-75; Omaha World Herald, October 5, 1936.

'Indianapolis News, August 1, 1936; New York Times, August 2, 1936; Paul Porter to Thomas T. Spencer, November 25, 1974, Author's Possession; Omaha World Herald, October 16, 1936; Gilbert C. Fite, "The Agricultural 
On August 25 the committee was officially announced to the public at an organizational meeting in Des Moines, Iowa. Present at the meeting were farm leaders from states in the Midwest and West. William Settle was named chairman of the Committee. Settle headed the Corn Belt Committee that lobbied for the McNary-Haugen Bill in the 1920s, and he had previously served as director of the Farmers National Grain Corporation under Herbert Hoover, and head of the Indiana Farm Bureau. He was often regarded as a "rural rabble-rouser" and "rustic hayseed" who spit tobacco juice at spittoons with only moderate success, but he was dedicated to solving the problems of the farmer and had a loyal following among farmers in Indiana. Other important committee members appointed were Representative Marvin Jones of Texas, chairman of the House Committee on Agriculture and Congressional advisor for the group; William S. Bradley, an Iowa Democrat and secretary-treasurer of the organization; and Paul Porter, chief of the Agricultural Adjustment Administration's press section who was executive director for the committee. ${ }^{7}$

Members and leaders selected to head state branches were also experienced in farm matters. Oscar Fosheim, chairman of the South Dakota committee, was formerly state vice president of the Farmers Union and he was regarded as a prominent farm leader and state representative. The Kansas committee included two state senators and Farm Bureau members, as well as the president of the Kansas livestock association, Grange members, and people involved with cooperative creameries and elevators. Homer Hush, organizer of the Des Moines gathering and chairman of the Iowa Agricultural Committee, was a farmer and Republican legislator who had been a member of the state legis-

Issue in the Presidential Campaign of 1928," The Mississippi Valley Historical Review, 37 (March, 1951): 655-656.

${ }^{7}$ Des Moines Register, August 25, 1936; Indianapolis News, June 27, August 1, 1936; Dean Albertson, Roosevelt's Farmer: Claude R. Wickard (New York, 1961), 40; Washington Evening Star, September 25, 1936; Roosevelt All-Party Agricultural Committee letterhead, Record Group 16 (hereafter cited as RAPAC) Secretary of Agriculture Papers, National Archives, Washington, D.C.; New York Times, September 22, 1936; New York Herald Tribune, August 25, 1936. 


\section{The Annals of Iowa}

lature in lowa from 1929 to 1936. In Wisconsin the committee was made up of members, officers and directors of leading farm organizations of the state. In some instances farm organizations played a part in helping select committee members. This was the case in Nebraska where the Farm Bureau assumed a major role in selecting members for the state organizing committee. ${ }^{8}$

Farmers who joined the committee did so because they believed Roosevelt and the New Deal to be their best hope. Joining the committee offered them the opportunity to work for the president's reelection, and it provided a vehicle through which they hoped to exert influence and make their suggestions on farm policy known. Paul Weis, chairman of the Wisconsin AllParty Agricultural Committee, summed it up best in a letter to the president midway through the campaign. He expressed the whole-hearted support of himself and the committee and offered suggestions on how to improve farm policy. He expressed the hope that the president would do all he could to adjust the inequality that existed in the Wisconsin allotment of the Soil Conservation Act. He wanted the president to be aware, also, of the necessity of liberalizing the policies of the Farm Credit Administration and of increasing the number of Wisconsin farmers who were involved in the Farm Bureau Federation and the National Grange. He further asked that the Agricultural Committee be consulted by the national administration on future proposed legislation. ${ }^{9}$

$N_{\text {ATIONAL headquarters for the committee were established }}$ in Chicago with the main organizing work delegated to the various state organizations. By November, committees had been established in fourteen states: Colorado, Illinois, Indiana, Iowa, Kansas, Montana, Minnesota, Missouri, Nebraska, North

${ }^{8}$ Sioux Falls Argus-Leader, August 13, 1936; Henry A. Wallace to L. E. Webb, November 30, 1936, RAPAC, Secretary of Agriculture Papers; Paul Weis to F.D.R., September 24, 1936, President's Personal File 4135, F.D.R. Library; F. L. Robinson to William H. Settle, November 9, 1936, Campaign of 1936-Roosevelt All-Party Agricultural Committee folder, George Norris Papers, Library of Congress, Washington D.C.

${ }^{9}$ Weis to F.D.R., September 24, 1936, President's Personal File 4135. 
Dakota, Ohio, South Dakota, Wisconsin, and Wyoming. The Committee was to conduct its own activities separate from the Democratic National Committee, but they were closely aligned with the regular party organization as an auxiliary group. Nearly all funding for the committee came from the Democratic National Committee and the Democratic party assigned one of its accountants to the agricultural committee to assure that all financial records were properly kept. ${ }^{10}$

Once underway, the agricultural committee utilized many different means to reach the midwestern farmer. Public speeches, personal appearances, printed material, radio broadcasts, newspapers, magazine ads, and circular letters were all used with a good deal of success. Rallies and speeches were the most important means used by the committee and they enlisted a number of prominent people who they were sure "could talk the farmers' language." 11

The most important speaker for the committee was the president. Roosevelt journeyed through the midwestern states twice during the campaign. The first time was a non-political visit in late August and early September to visit states devastated by the drought. In October he undertook a second campaign trip, visiting Iowa, Minnesota, Nebraska, Kansas, Colorado, Missouri, Illinois, Michigan, Ohio, and upstate New York. Roosevelt courted the farm vote by delivering speeches that emphasized the benefits of the New Deal's farm programs. He did not speak under committee auspices, but he did meet with leaders of the committee, and his appearances aided the committee's efforts in the Midwest. ${ }^{12}$

The president did give one radio speech under the committee's

${ }^{10}$ Des Moines Register, August 25, 1936; RAPAC, Secretary of Agriculture Papers; Homer Hush to Author, November 3, 1974; Memorandum from Chester C. Davis to James A. Farley, July 16, 1936, Correspondence, Wallace Papers, University of Iowa; 75 Congress, 1 Session, Senate Report 151, Investigation of Campaign Expenditures in 1936 (Washington, 1937), 26.

${ }^{11}$ New York Times, August 2, 1936.

${ }^{12}$ Milo Perkins to Paul Appleby, September 30, 1936, RAPAC, Secretary of Agriculture Papers. 
sponsorship on a radio broadcast known as the "Roosevelt Sunrise Hour." This program, devised by Paul Porter especially for the campaign, was designed to present special pro-Roosevelt broadcasts to the farmers early in the morning when they were having their breakfast. ${ }^{13}$ There is no evidence what kind of response these broadcasts drew, but the project was unique and showed the agricultural committee to be in tune with its audience.

Among other prominent speakers to appear under committee sponsorship were Secretary of Agriculture Henry Wallace and Congressman Marvin Jones. Most of their speeches were directed toward farmers, farm problems, and the reciprocal trade treaties, but numerous references were made to the ineptitude of previous Republican administrations and the big money interests supporting the Landon candidacy.

Nowhere are these themes better illustrated than in the campaign addresses given by Henry Wallace. Besides helping organize and coordinate the activities of the agricultural committee, Wallace conducted a major speaking tour through Illinois, Minnesota, Iowa, Michigan and Kansas. At DeKalb, Illinois Wallace spoke under the committee's auspices and criticized Republican critics of the New Deal for sowing seeds of discord by pitting section against section and class against class. He stated that the Republicans were falsely telling farmers that the reciprocal trade agreements were sacrificing farmers' interests in favor of the workers of the cities. Speaking before a committeearranged gathering of farmers in Fairmont, Minnesota, Wallace criticized the Republican "market basket" campaign. The "market basket" was a pamphlet published by the Women's Division of the Republican National Committee that blamed the New Deal for taxes on ordinary household purchases and higher food prices. He labeled this campaign "damnable propaganda" and charged that Landon was intending to deliver the country back to the control of bankers. On October 30, Wallace delivered his biggest speech in Des Moines before 2,500 people and a nationwide radio audience. In this address, Wallace castigated Landon's agricultural policy by labeling it a three-way

${ }^{13}$ Paul A. Porter to Author, November 25, 1974. 
proposition. He likened it to the Hoover farm board, the Smoot-Hawley tariff, and the Hoover gold standard all in one. He also associated Landon with the "munition makers and other birds of prey" and called on the Republican candidate to repudiate the support of the Liberty League. ${ }^{14}$

Another popular committee speaker was Marvin Jones. As director of the committee's speakers bureau, Jones traveled extensively throughout the farm belt giving numerous speeches. In Des Moines he spoke before a committee-sponsored rally of 1,500 people and assailed the Landon farm plan, while supporting Roosevelt's program. He spoke highly of the reciprocal trade treaties and chided Landon for associating with Liberty Leaguers and big financiers. In an address in Minneapolis, that also featured Secretary of State Cordell Hull, Jones criticized Landon's proposal for temporary cash payments to growers of surplus crops. Jones once again praised the Roosevelt program, as did Cordell Hull, who staunchly defended the administration's trade agreements program. ${ }^{15}$

Speakers were used by the committee in other ways as well. In addition to the "Roosevelt Sunrise Hour," the committee sponsored a number of radio broadcasts that featured national and local farm leaders. In Iowa and Nebraska special radio interviews and dialogues were conducted with farmers who were attuned to the agricultural problems in those states. In Iowa, farmers were also used as speakers on special motor caravans that toured the state with speaker trucks and literature. On one particular day, a committee-sponsored caravan of 350 cars toured every town in Hardin County, Iowa, stopping in each town to give a least a short speech. ${ }^{16}$

The agricultural committee placed primary emphasis on

${ }^{14}$ Des Moines Register, October 18, 26, 30, 1936; Charlotte Observer, October 20, 1936; Minneapolis Tribune, October 21, 1936; Washington Evening Star, October 18, 1936.

${ }^{15}$ Des Moines Register, September 24, 25, 1936; Washington Evening Star, September 25, 1936; Minneapolis Tribune, October 4, 8, 1936.

${ }^{16}$ Des Moines Register, October 18, November 1, 1936; F. L. Robinson to William H. Settle, November 9, 1936, Campaign of 1936, Roosevelt All-Party Agricultural Committee folder, Norris Papers. 


\section{The Annals of Iowa}

speeches and speakers who could relate to farm problems, but they also published a great amount of literature in the form of pamphlets, newspaper ads and farm journal advertisements. The literature, like the speakers, directed itself to the important farm issues. The committee published and distributed a total of thirteen pamphlets. By mid-October, the Omaha World-Herald related that 2,000,000 copies of eleven of these pamphlets had been distributed in the farm belt. The biggest pamphlet was a thirty-two page illustrated booklet entitled What About the Farmer? Another publication, The Truth About Farm Imports, was a circular that defended the Roosevelt program and attacked the Republicans. The pamphlet charged that the rumor that imports ruined the farmer was started by the American Liberty League "and other dummies," and further emphasized the disastrous effects of the high Republican tariffs in the 1920s. Who's Against Roosevelt? was a pamphlet that listed New Deal critics as the grain gamblers, packers trust, crooked politicians, tariff pirates, the power trust, and money changers. Other pamphlet titles included Goodbye to Farm Drudgery-The Story of Rural Electrification, What About the National Debt?, Our Foreign Trade Program, When Drought Comes, Why Cattlemen Will Support Roosevelt, Why Dairymen Will Support Roosevelt, Words vs. Action, and Roosevelt Made Bank Deposits Safe. ${ }^{17}$

Other committee propaganda appeared in farm journals and newspapers. The committee ran ads in the Wisconsin Agriculturalist and Farmer, Prairie Farmer, and Wallace's Farmer and lowa Homestead. One such ad centered around the question "Remember 1932?" Listed in bold letters was the price of farm goods in 1932, and the ad described how the New Deal farm programs had brought significant increases. Another ad was entitled "Golden Apples" and accused Republican candidate Landon of offering the farmer a golden apple program on a platform of platitudes. The ad asked "why swap performance for

${ }^{17}$ Clipping from Omaha Herald, October 16, 1936, Clipping Book \#4, Good Neighbor League Records, F.D.R. Library; Printed Material 1936-1938, Container 1205, Democratic National Committee Records; List of Pamphlets Published in a Committee advertisement in Wallaces' Farmer and lowa Homestead, October 10, 1936. 
platitudes?" Included in each advertisement was a coupon that the reader could send to obtain free literature and committee material. Newspaper ads were also used effectively. The Nebraska committee was especially lavish in sponsoring such ads. In the last week of the campaign, ads were run in 140 newspapers scattered throughout that state with at least one paper in each county included. ${ }^{18}$

Circular letters were yet another means of propaganda. In South Dakota the agricultural committee sent letters throughout the state in an attempt to undermine the third party candidacy of South Dakotan William Lemke who was running on the Union Party ballot. Committee letters were sent to all residents who had signed the Lemke-O'Brien nominating petition. The letters urged voters not to waste their vote on a candidate who had no chance of winning the presidency. Instead, petition signers were encouraged to vote for Lemke for the House of Representatives, where he was also on the ballot. ${ }^{19}$

As an auxiliary group, the All-Party Agricultural Committee maintained a good working relationship with the Democratic party, but there were occasional instances of friction between the committee and the regular party organization. In Iowa trouble arose over the refusal of the Iowa agricultural committee to support local Democratic candidates. Except for Nebraska, where the committee campaigned for George Norris, the agricultural committee stayed clear of local campaigns, and local Demoractic leaders in Iowa became upset when the committee would not endorse them. One Democratic leader in Iowa was also angered for what he felt was the committee's failure to cooperate and keep him informed of the rallies they sponsored. He called the committee a "failure." 20

${ }^{18}$ Wallaces' Farmer and lowa Homestead, September 26, 1936, 657, and October 10, 1936, 687; For ads in other farm magazines see Prairie Farmer, October 24, 1936, and Wisconsin Agriculturalist and Farmer, September 26, 1936; For newspaper ads see Robinson to Settle, November 9, 1936, Campaign of 1936, Roosevelt All-Party Agricultural Committee folder, Norris Papers.

${ }^{19}$ New York Times, August 2, 1936; Sioux Falls Argus-Leader, October 31, 1936.

${ }^{20}$ Homer Rush to Author, November 3, 1974; L. S. Hill to James A. Farley, September 29, 1936, Correspondence of James A. Farley, 1936, Democratic National Committee Records. 
The situation in Nebraska caused problems of a similar type. Frank Robinson, chairman of the Nebraska committee, noted in a letter to William Settle that the agricultural committee did not have a friendly and sympathetic relationship with the Democratic state committee. In some cases Democratic leaders refused to cooperate, such as in Nebraska's fifth district where Congressman Harry Coffee instructed Marvin Jones not to mention the president's or George Norris' name when Jones was speaking there. Coffee was said to be pursuing a "lone wolf" policy and neglecting both Roosevelt and Norris. ${ }^{21}$ Disputes, like those that occurred in Iowa and Nebraska, are not uncommon whenever party and non-party workers come together, but the clashes did not prevent the committee from making a significant contribution to the campaign in those states.

Expenditures of the All-Party Agricultural Committee reveal much about the nature and extent of the organization's activities and its close alignment with the Democratic National Committee. The committee spent a not insignificant total of $\$ 255,485.35$ in the campaign. Of this amount, $\$ 244,086.64$ came from the Democratic National Committee. The remainder came from individual contributions. Among the individual contributors were agricultural leaders Henry Wallace, Chester Davis, Milo Perkins, and Alfred Stedman. ${ }^{22}$ The National headquarters in Chicago spent $\$ 120,120.85 ; \$ 10,412.12$ of it going for radio broadcasts, $\$ 24,318.37$ for newspaper advertising, and $\$ 47,317.77$ for printing. The most active states were Minnesota $(\$ 20,000.00)$, Iowa $(\$ 17,497.00)$, and Nebraska $(\$ 14,556$.$66)$. The least active states were Wyoming $(\$ 1,653.92)$, Colorado $(\$ 5,806.52)$, and Montana $(\$ 5,125.06)$. These were all states that did not organize committees until late in the campaign. The state committees and national headquarters com-

${ }^{21}$ F. L. Robinson to William H. Settle, November 9, 1936, Campaign of 1936, Roosevelt All-Party Agricultural Committee folder, Norris Papers, Democratic National Committee Records; J. E. Lawrence to Stanley High, October 3, 1936, Campaign of 1936, Democratic National Committee folder, Norris Papers.

${ }^{22}$ Roosevelt Agricultural Committee Disbursements, August 24 to November 24, 1936, Correspondence, Wallace Papers, University of lowa; 75 Congress, 1 Session, SR 151, Investigation of Campaign Expenditures in 1936, 26, 52, 59, 98, 112, 120; New York Post, October 21, 1936. 
bined spent $\$ 40,903.65$ for traveling expenses, $\$ 17,592.49$ for radio, $\$ 42,040.08$ for newspaper ads, and $\$ 52,215.33$ for printing and literature. ${ }^{23}$

B Y THE conclusion of the campaign, committee leaders had become more optimistic about their chances in the Midwest and even returned some funds to the Democratic National Committee. ${ }^{24}$ On November 5 voters went to the polls and proved the committee's optimism was well founded. Roosevelt received the largest electoral mandate to date by gathering 523 electoral votes to Landon's eight. The president received $27,478,945$ popular votes to his challenger's $16,674,665$ and he carried every state but Maine and Vermont. The Midwest remained solidly behind Roosevelt as it had in 1932. Roosevelt's vote total in Nebraska, South Dakota and North Dakota decreased from what it was in 1932, but in eleven other states where the All-Party Agricultural Committee was active, Roosevelt received more votes than he had in 1932. In Ohio, the president captured six more counties than he had in 1932 and carried fifty-eight rural counties to Landon's twenty-two. ${ }^{25}$

Determining how many votes the agricultural committee directly influenced by its efforts is impossible and it is evident from the enormity of the landslide that there were many other voter groups that helped keep Roosevelt in office. Nonetheless, the success of the All-Party Agricultural Committee as an effective propaganda and publicity unit that enlisted midwestern farmers behind Roosevelt cannot be denied. The committee helped counter Republican criticism of the reciprocal trade treaties, while publicizing the achievements of the New Deal. In every state where the committee was active it proved to be more than just a paper organization. In lowa, for example, more than ninety of the ninety-nine counties had active county and town-

\footnotetext{
${ }^{23}$ Roosevelt Agricultural Committee Disbursements, August 24 to November 24, 1936, Correspondence, Wallace Papers.

${ }^{24}$ Paul A. Porter to Author, November 24, 1974.

${ }^{25}$ Edgar Eugene Robinson, They Voted for Roosevelt: The Presidential Vote, 1932-1944 (Stanford, 1947), 59-183; Myron B. Steiner to M. L. Wilson, November 7, 1936, Record Group 16, Secretary of Agriculture Papers.
} 
ship chairmen, while Nebraska claimed an organization in each of the state's ninety-three counties. ${ }^{26}$ Speakers and literature addressed topics of importance to farmers in language they could easily relate to. By organizing a separate agricultural committee, the Democrats involved many farmers and agricultural leaders who might not otherwise have become involved in the campaign. This also helped create the impression that there was a groundswell support for Roosevelt among farmers.

Although the Democrats benefited from the committee's work, there is little evidence to indicate that the committee was able to exert much influence on the president regarding the formation of agricultural policy. The committee discontinued its activities shortly after the election. There is no indication whether committee leaders were influential in the passage of agricultural legislation during Roosevelt's second term. Roosevelt continued to obtain support from midwestern farmers, but there was a gradual erosion of such support in future elections. In 1940 Roosevelt lost Kansas, Nebraska, South Dakota and North Dakota, and in 1944 he lost these same states plus Ohio and Wisconsin. ${ }^{27}$

A study of the All-Party Agricultural Committee in the election of 1936 justifies several conclusions about midwestern farmers and the New Deal. First, it supports the claim of historians that farmers were part of the Roosevelt coalition in 1936 and shows that bringing farmers into this coalition was not a chance occurrence, but a well-planned political move whose basic premise was the New Deal legislative program for farmers. Democrats attached a great deal of importance to the farm vote in 1936 and they were genuinely worried that the president would lose several midwestern states. Although their fears proved to be exaggerated, the committee's work did much to attract farmers in the region, as well as offering independents and Republicans, who preferred Roosevelt more than the Democratic party, an organization through which to participate.

\footnotetext{
${ }^{26}$ Homer Hush to Author, November 3, 1974; Omaha World Herald, September 19, 1936.

${ }^{27}$ See Robinson, They Voted for Roosevelt, 59-183.
} 
The work of the committee also illustrates that despite many New Deal agricultural achievements, there were some issues, such as the reciprocal trade agreements, which were upsetting to farmers. The agricultural committee did much to help counter criticism of these agreements and it provided a wellorganized propaganda vehicle with which to counter New Deal opponents.

Finally, the activities of the committee show that farmers were politically active during the New Deal period. Standard accounts of the 1936 election stress the important political contributions made by labor, women and black Americans in the campaign, ${ }^{28}$ but farmers, too, were extensively involved in the reelection effort. They believed Roosevelt to be their best hope and they were anxious to leave no stone unturned to return him to office.

The 1936 election marked the pinnacle of Roosevelt's support from the midwestern farm belt. The activities of the All-Party Agricultural Committee attest to the importance with which Democrats viewed farmers as well as the vital role the committee played in the campaign. For these reasons, the Roosevelt All-Party Agricultural Committee remains a good case study of the political impact of farmers on a presidential election campaign.

${ }^{28}$ See, for example, William E. Leuchtenburg, "The Election of 1936," in Arthur M. Schlesinger, Jr. and Fred Israel, eds., A History of American Presidential Elections, 4 Vols. (New York, 1971), 3:2809-2914; Donald R. McCoy, "The Election of 1936," Crucial American Elections, (Philadelphia, 1973), 55-73. 
Copyright of Annals of Iowa is the property of State of Iowa, by \& through the State Historical Society of Iowa and its content may not be copied or emailed to multiple sites or posted to a listserv without the copyright holder's express written permission. However, users may print, download, or email articles for individual use. 